\title{
Inequality in education in Costa Rica: The gap between students in public and private schools. An analysis of the results of the Programme for International Student Assessment (PISA)
}

Andrés Fernández A. and Roberto Del Valle A.

ABSTRACT

This article presents the main results of the Programme for International Student Assessment (PISA) for Costa Rica in 2009 and then goes on to analyse the gap between the scores of students attending private schools and those attending public schools. However, the estimation of an education production function using these data shows that this gap is not entirely attributable to whether schools are public or private, but that instead the students' family environment, personal traits and, in particular, the student's grade level at the time that the PISA test was taken are all quite influential.

KEYWORDS JEL CLASSIFICATION
Education, quality of education, scholastic achievement, educational achievement, measurement, public schools, private schools, education statistics, Costa Rica

$\mathrm{I} 21, \mathrm{I} 24, \mathrm{O} 38$

Andrés Fernández A. holds a degree in economics from the University of Costa Rica. affa17@gmail.com Roberto Del Valle A. holds a degree in economics from the University of Costa Rica. roberto.dva@gmail.com 


\section{I}

\section{Introduction}

For the first time ever, Costa Rica took part in the Programme for International Student Assessment (PISA) in 2010 under the PISA 2009 PLUs Project, which administered the test to a sample of Costa Rican 15-yearolds from various schools in the country. In December 2011, the test results were published. The results showed that Costa Rica had the second-highest score in Latin America in reading and sciences and the fifth-highest in mathematics, although it still ranked far below the member countries of the Organization for Economic Cooperation and Development (OECD).

Apart from the overall results, the data obtained from the PISA assessment, together with the information supplied by the questionnaires to which students and school administrators responded, provide some idea of the quality of the Costa Rican educational system and provide an opportunity for gauging not only how well or poorly its system measures up against those of other countries, but also for determining what kinds of educational differences exist within Costa Rica itself.

While it is true that the gap in scores separating Costa Rica from developed countries is quite wide and

$\square$ The authors are grateful to Ronulfo Jiménez Rodríguez, Professor of Economics at the University of Costa Rica, for his comments and insights regarding the PISA results and to Pablo Zoido, a PISA Analyst, for the guidance he provided regarding the processing of the data. merits a more detailed examination, an analysis of the educational gaps existing within a country can yield more relevant findings for the formulation of educational policies designed to narrow the quality gap and offer the same educational opportunities to all young people in that country.

The objective of this article is to undertake a detailed analysis of young Costa Ricans' performance on the 2009 PISA test, the main factors influencing that performance and the differences between the scholastic achievement levels of students in public and private schools.

Following this introduction, section II offers an overview of the educational system in Costa Rica. Section III provides an explanation of what the PISA assessment entails and details the scores obtained by Costa Rican students on that test. Since this was the first time that these data have been compiled, and the results of the assessment have not been widely publicized, a comparison of the overall results for Costa Rica with those of other countries in the region is presented in section IV.

In section $\mathrm{V}$, we construct an education production function for use in analysing the determinants of students' performance on the PISA test. In section VI, we present the results obtained at the national level and then use Fields' decomposition technique to analyse the determinants of students' performance differentials. Our findings are presented in section VII.

\section{II}

\section{Education in Costa Rica}

\section{The Costa Rican education system}

In Costa Rica, the school system is divided into preschool, a basic general education (primary and lower-secondary) level, upper-secondary school and higher education. Preschool and the basic general education level are both compulsory, and they, as well as upper-secondary school, are free and are funded by the State.

The basic general education level is composed of three compulsory cycles. Cycle I (first, second and third grades) and cycle II (fourth, fifth and sixth grades) are included in primary school. Upon completion of cycle II, students receive a primary school diploma. Cycle III (seventh, eighth and ninth grades) is the last compulsory cycle. A secondary education is composed of cycle III and cycle IV (known as "diversified education"). Cycle IV lasts from two to three years and is subdivided into three streams: the academic stream and the arts stream each take two years (tenth and eleventh grades) to complete, while the technical stream (which is given 
in vocational schools) is three years in length (tenth, eleventh and twelfth grades). Students in this last stream can choose to specialize in industrial, commercial or agricultural courses. Students complete the academic stream upon successfully sitting the final baccalaureate examination, whereupon they earn a secondary school diploma. Students in the arts and technical streams can also earn a secondary school diploma if they pass the final baccalaureate examination. Students in the technical stream are awarded a technical school diploma upon their successful completion of their studies. ${ }^{1}$

\section{Costa Rica and international assessments}

The PISA test is not the first international assessment in which Costa Rica has participated. Third- and fourthgrade Costa Rican students took part in the Latin American Laboratory for Assessment of the Quality of Education (LLECE), which was administered by what is now the UNESCO Regional Bureau for Education in Latin America and the Caribbean in 1997, and thirdand sixth-graders took part in the Second Regional Comparative and Explanatory Study (SERCE) between 2004 and 2008.

\footnotetext{
1 In addition to traditional schools, there are a number of other programmes that are open to young people and adults who, for whatever reason, were unable to follow a formal course of study. These mechanisms include night schools and special programmes such as remedial primary and secondary school courses for adults, distance learning programmes, open classrooms, the New Opportunities Programme and the Comprehensive Education Centre for Young People and Adults (CINDEA).
}

In the first assessment, the results for Costa Rica were not included in the score reports or in the statistical parameters for the various studies that were prepared because the data which the country provided did not meet the required technical standards of LLECE. In the second assessment, Costa Rica was one of the highestranking countries in the region (students in 16 countries were evaluated), with its third- and sixth-grade students scoring in third place in mathematics and in second place in reading (UNESCO, 2008).

\section{Studies on the quality of education in Costa Rica}

The first effort to estimate the effect of different factors on scholastic achievement in Costa Rica dates back to 1980 (Díaz and Jiménez, 1980). Based on their estimate of an education production function using data at the cantonal level, the authors of that study concluded that both school inputs and socioeconomic factors influence scholastic achievement. Moreira (2009) has analysed how various factors influenced the scores obtained on the national baccalaureate mathematics test in 2004 by eleventh-grade students attending academic day schools. Using a multilevel analysis, the author finds that endogenous factors such as students' academic records and, more specifically, the fact that students have or have not repeated a grade and the educational level of their parents, correlate with their scores.

No studies that have drawn on the databases of international assessments for Costa Rica have been conducted, however, and this research effort is therefore one of the first to contribute to the debate concerning educational quality and inequality.

\section{III}

\section{The Programme for International Student}

\section{Assessment (PISA)}

\section{What is PISA?}

The Programme for International Student Assessment (PISA) is a joint initiative of the OECD member countries aimed at measuring how prepared 15-year-old students (who are about to complete their compulsory education) are to cope with the challenges involved in living in today's society.
The assessment is forward-looking: rather than trying to measure specific areas of knowledge based on each school's curricula or programmes of study, it focuses on evaluating students' ability to use their knowledge and skills to meet life challenges.

PISA surveys and assessments are conducted every three years. They all measure skills and knowledge in the areas of reading, sciences and mathematics, but each 
time emphasis is placed on one of these three subject domains, with nearly $60 \%$ of the assessment being devoted to that subject. The first assessment, in 2000, focused on reading; the second, in 2003, concentrated on mathematics; and the third, in 2006, placed greater weight on the sciences. These three tests made up the first full cycle of PISA assessments.

The second cycle of assessment tests started off in 2009; the focus of this round was on reading. This was the first time that Costa Rica had taken part in PISA. The last test was conducted in 2012.

In addition to using a written test to measure students' abilities and knowledge, PISA also sends out questionnaires to students and school administrators in order to gather information that it can then use to analyse the test results and place them in their proper context.

\section{The PISA 2009 results: Costa Rica's ranking}

Originally, 64 countries (9 of them in Latin America) participated in the 2009 assessment. In 2010, another 10 countries took part in the PISA 2009 PLUS project; students in these countries took the same tests that their counterparts had in 2009. Costa Rica was the only Latin American country to join the PISA 2009 PLUS project.

The values attached to the students' performance on the test are called "plausible values" and are regarded as continuous latent variables, which means that they are dealt with as measureable quantities for which no measuring instrument exists; ${ }^{2}$ in the PISA assessment, the items are not evaluated as specific scores but instead using comparative scales. In order to facilitate the interpretation of the students' scores, the scales for reading, mathematics and science have been designed so that the average score will be 500 points for OECD member countries, with a standard deviation of 100 points. This means that two thirds of students in OECD member countries obtain between 400 and 600 points (OECD, 2009, p. 136).

2 In this type of educational assessment, which is based on the Rasch statistical model, students do not earn additional points for each correct answer; instead, points are awarded on the basis of the type of answer given. The Rasch model is used to create scales for measuring the possible answers that students might give based on the level of difficulty of the question or item.
In the reading assessment, the Latin American countries were all in the bottom half of the ranking, with all of them obtaining average scores below the mean for OECD member countries (see table A.1 of the annex). Chile had the highest ranking among the Latin American countries, with 449 points, followed by Costa Rica with 443 points.

In the mathematics assessment, Uruguay was the highest-ranking Latin American country, with 427 points. Costa Rica, with just 409 points, ranked fifth among the Latin American countries and 55th overall; this was its lowest ranking of all. In science, the situation was similar to the results for the reading assessment: Chile was in first place, with 447 points, and Costa Rica was in second with 430 points.

\section{- Proficiency scales}

In addition to reporting the students' overall score, the PISA assessment also provides information on competencies by placing students on a scale that describes what they know and what they can do.

These scales are called "proficiency scales" rather than "performance scales" or "achievement scales" because they provide information on what the students know and what they can do at certain levels rather than on how they performed on the (one-time) assessment. This approach is used because the objective of the PISA assessment is to gauge students' overall level of competence rather than their performance on a specific test.

PISA defines seven levels of reading proficiency, ranging from level $1 \mathrm{~b}$ (ability to perform elementary tasks that require very basic reading skills) to level 6 , which involves sophisticated tasks that can generally be completed only by highly proficient readers. The PISA programme classifies level 2 as the baseline level of competency at which students are beginning to exhibit reading skills that will enable them to play an effective role in real-life situations.

In Chile and Costa Rica, nearly one third of the students display levels of proficiency that are below the baseline (level 2), and that another third are at that level. This means that one out of every three students does not have the basic cognitive tools in the area of reading needed to cope with future life challenges and another third has just barely reached that skill level. 


\section{IV}

\section{Analysis of the PISA results for Costa Rica}

\section{Construction of the sample used in the PISA assessment}

The PISA sample is drawn from a target population of students ranging from 15 years and three months to 16 years and two months of age who attend established schools and are in seventh grade or above. For the sake of convenience, reference will be made to this target population as being made up of 15-year-old students.

The sample for education studies is generally not based on a simple random sampling of the target population. Instead, the sample is constructed in two stages. In the first stage, a sample of schools is selected from a complete list of all the schools attended by the target population of students. For the PISA test, all the schools have a probability of being selected that is proportional to their size. In addition, a standard minimum participation rate at the school level of $85 \%$ is used in order to reduce the non-response bias. In the case of Costa Rica, the effective school participation rate was $99.43 \%$.

In the second stage, the sample of students in the selected schools is chosen at random. PISA studies indicate that a minimum of 35 students of 15 years of age are chosen in each participating school. In Costa Rica, 4,578 students were assessed, which amounts to a participation rate at the student level of $94.45 \%$ (the minimum standard established by PISA is $80 \%$ ). ${ }^{3}$

Selected data concerning this sample group of students are provided in table A.2 of the annex. In this and all other tables included in this article, the standard deviation is given in brackets. ${ }^{4}$

\footnotetext{
3 The coverage index for the population of 15 -year-olds was 0.53 points. This is a limitation shared by studies that use these databases, since they exclude the population of 15 -year-olds who are not attending established schools, who have dropped out, who never attended school or who were otherwise excluded from the education system. This could generate a selection bias. This study is therefore representative only of students attending established rural or urban academic or vocational day schools.

4 All the averages cited in this article are weighted averages computed using the final student weightings (W_FSTUWT) of the PISA databases. In order to calculate the standard deviation, the balanced repeated replication (BRR) method recommended by PISA was employed with 80 other replicates (W_FSTR1,W_FSTR2...,W_FSTR80) as specified in chapters 7 and 8 of the PISA Data Analysis Manual (OECD, 2009).
}

In all, 53\% of the students who were assessed were female, and $85 \%$ of the students were enrolled in public schools. Although the usual grade level of a 15-year-old in Costa Rica is ninth grade, students in almost all grade levels were assessed, although the great majority were in the ninth or tenth grades (75\%). Most of the students who were in seventh grade were there because they had had to repeat one or more grades.

\section{Analysis of education gaps}

Various types of gaps in education may exist. Some of the most common are gender gaps, gaps that can be categorized on the basis of the area or sector in which a school is located and gaps between different types of schools.

Table 1 outlines the PISA test performance differentials, disaggregated by gender and by type of school, for each of the knowledge domains that were assessed. Differentials corresponding to school locations are not provided because the PISA programme does not compile information on students' area of residence.

\section{- Gender gaps}

In the 2009 assessment, females outperformed males on the reading test in all of the participating countries. As shown in table 1, the gender gap in reading skills in Costa Rica amounts to 14 points. Costa Rica is one of the countries in which this gap is the narrowest, however.

In contrast, males outperformed females in mathematics and science, with women scoring, on average, 26 points below males in mathematics and 17 points below them in science.

\section{— Gaps by type of school}

The widest gaps appear when students' scores are disaggregated by the type of school that they attend. In all three domains, students attending private schools outperformed, on average, those attending public schools. In reading, the differential was 86 points; in mathematics, it was 79 points; and, in science, it was 84 points.

Only $5 \%, 16 \%$ and $8 \%$ of the students attending private schools scored below the baseline proficiency 
TABLE 1

Costa Rica: average scores on the 2009 PISA test and education gaps, by domain

\begin{tabular}{|c|c|c|c|c|c|c|}
\hline \multirow{2}{*}{ Category } & \multicolumn{2}{|c|}{ Reading } & \multicolumn{2}{|c|}{ Mathematics } & \multicolumn{2}{|c|}{ Science } \\
\hline & Score & Gap & Score & Gap & Score & Gap \\
\hline \multirow[t]{2}{*}{ General } & 443 & & 409 & & 430 & \\
\hline & $(3.2)$ & & $(3.0)$ & & $(2.8)$ & \\
\hline \multicolumn{7}{|l|}{ Gender } \\
\hline Female & $\begin{array}{c}449 \\
(3.0)\end{array}$ & 14 & $\begin{array}{c}397 \\
(3.1)\end{array}$ & -26 & $\begin{array}{c}423 \\
(2.8)\end{array}$ & -17 \\
\hline Male & $\begin{array}{c}435 \\
(3.7)\end{array}$ & (2.3) & $\begin{array}{c}423 \\
(3.4)\end{array}$ & (2.1) & $\begin{array}{c}440 \\
(3.3)\end{array}$ & (2.4) \\
\hline \multicolumn{7}{|c|}{ Type of school } \\
\hline Public & $\begin{array}{c}429 \\
(3.1)\end{array}$ & -87 & $\begin{array}{c}397 \\
(2.8)\end{array}$ & -79 & $\begin{array}{c}418 \\
(2.7)\end{array}$ & -84 \\
\hline Private & $\begin{array}{c}516 \\
(5.7)\end{array}$ & $(6.5)$ & $\begin{array}{c}476 \\
(5.8)\end{array}$ & $(6.3)$ & $\begin{array}{c}502 \\
(5.7)\end{array}$ & (6.2) \\
\hline
\end{tabular}

Source: prepared by the authors on the basis of the 2009 PISA assessment database.

Note: the standard deviation is shown in brackets.

levels for reading, mathematics and science, respectively, whereas the corresponding percentages for public-school students were $38 \%$ in reading, $61 \%$ in mathematics and $45 \%$ in science.

Thus, $73 \%$ of private-school student scored in one of the top four proficiency levels for reading (versus $25 \%$ of public-school students), $50 \%$ of private-school students did so for mathematics (versus $11 \%$ of publicschool students) and $61 \%$ of private-school students did so for science (versus $16 \%$ of public-school students).

\section{Public-school/private-school differentials}

The survey form includes questions about the presence in the home of certain items that may facilitate learning. For example, respondents are asked whether the students have a room of their own or a desk where they can study. In both cases, nearly $90 \%$ of private-school students had these two items, where the figure was below $70 \%$ for public-school students (see table A.3 of the annex).

Another factor identified in the literature as influencing scholastic achievement is access to information and communications technologies (ICTs). In this case, the gap between public- and private-school students is even wider: nearly $100 \%$ of Costa Rican students who attend private schools have computers that they can use for their studies, and $91 \%$ have Internet connections in their homes, whereas just slightly more than half of their counterparts who attend public schools have computers $(56 \%)$, and less than one third of them $(31 \%)$ have Internet hook-ups in their homes.

An analysis of the employment status of the students' parents indicates that more of the fathers of private-school students are employed full-time ( $83 \%$, compared to $70 \%$ of the fathers of public-schools students); the same is true of their mothers (45\% versus $25 \%$ ). In addition, more of the mothers of public-school students do not work outside the home $(62 \%$ versus $41 \%$ of the mothers of private-school students) (see table A.4 of the annex).

The percentage of fathers of private-school students who have no more than a primary education is around $12 \%$, whereas the percentage of fathers of public-school students in that category is over $50 \%$, and $13 \%$ of that group has not completed any level of education at all. At the other end of the spectrum, approximately $15 \%$ of the fathers of public-school students have at least some higher education, whereas this figure is about $60 \%$ in the case of parents who send their children to private schools.

Two of the factors that differ the most between public and private schools are the percentage of teachers who have a postgraduate degree of some sort $(37 \%$ in public schools versus $50 \%$ for private schools) and the availability of computers in the schools; in public schools, there is an average of 1 computer for every 5 students of 15 years of age, whereas, in private schools, the ratio is 4 computers for every 5 students in that age group. 


\section{V \\ The education production function}

\section{Basic considerations}

The education production function (EPF) is the tool that most researchers use to measure the quality of education and its determinants. Todd and Wolpin (2003) outline a number of fundamental considerations relating to this function that will be summarized here.

Theories about the quality of education and its determinants are based on an analogy between the process by which human beings acquire knowledge and skills and the production process of a business, and they therefore focus on the mix of production factors or inputs that are used in conjunction with a given production technology to generate a product or output. In the case of education production functions, these factors are used to produce a given cognitive output which is then measured by means of a given test or assessment.

In order to measure the quality of education using an EPF, a range of information is needed on the factors to which each individual has been exposed since birth that could influence that individual's cognitive achievement at a given point in time. In other words, past and present information on family- and school-related factors is needed, as well as information on the individual's initial endowments, in order to evaluate the effects of those factors on his or her cognitive performance.

The databases used to conduct EPF analyses usually contain information on school- and family-related factors, but only data provided by one-time measurements; in addition, and especially in the case of family-related factors, the information is contemporary, that is, data on those factors at times prior to the assessment are not available. This is why many studies that use EPF analyses treat education-related factors at earlier stages of a person's life as unobservable values and make assumptions that allow them to be disregarded or set aside.

\section{General model}

The general model used to analyse cognitive achievement assumes that an individual's performance, as measured by a specific assessment at a given age, is the result of a cumulative process of knowledge acquisition.

Let $T_{i j a}$ be the measurement of the performance of individual " $i$ ", who lives in home " $j$ " and is " $a$ " years old. $F_{i j a}$ is the vector of family-related factors at a given age, and $S_{i j a}$ is the vector of school-related factors. The vectors that represent the cumulative data on each of the factors at age " $a$ " are $F_{i j}(a)$ and $S_{i j}(a)$. The individual's initial endowment of abilities or skills is represented by $u_{i j 0}$. Taking into account the error measurement for the test results $\left(\epsilon_{i j a}\right)$, the education production function is expressed as follows:

$$
T_{i j a}=T_{a}\left[F_{i j}(a), S_{i j}(a), u_{i j 0}, \epsilon_{i j a}\right]
$$

The empirical application of this method runs up against two problems, however:

(i) the genetic endowment of an individual is not measurable and is therefore an unobservable variable;

(ii) the data on the various factors are incomplete, either because a full range of data is unavailable or because the data on certain factors are missing. In order to deal with these problems, three approaches for specifying the model, each based on differing variants and assumptions, are discussed in the literature on production functions (Todd and Wolpin, 2003, pp. F16, F27).

The specification used in this study is a contemporary one based on the assumption that the ultimate assessment of cognitive achievement as measured using a test or other form of evaluation is related solely to the contemporary status of family- and school-related factors.

Bearing this assumption in mind when the time comes to analyse the results, the education production function can be expressed using the following equation:

$$
T_{i j a}=T_{a}\left(F_{i j a}, S_{i j a}\right)+\epsilon_{i j a}^{\prime}
$$

where $\epsilon_{i j a}^{\prime}$ is an additive error term. In this specification, the error term includes all omitted factors (the past history of such factors, the initial endowment of capacities and the error measurement).

While it is true that this specification is subject to certain limitations, this does not nullify the function's explanatory power inasmuch as, to date, very little research has been done on the quality of education in Costa Rica. It is therefore hoped that this study can offer some practical guidelines for future research. 


\section{Determinants of the quality of education}

Studies that use education production functions usually group all the different factors that could influence a student's learning process into three main categories: family-related and student-specific factors; school-related factors; and institutional and educational policy-related factors. A description of some of these factors, based on the compilation prepared by Vegas and Petrow (2007), follows.

\section{- Family-related and student-specific factors}

These factors have to do with traits of students and their families that are present before the students enter the school system. The age at which students begin their primary education and the preparation they receive before they do so have come to be seen as highly influential factors (Urzúa and Veramendi, 2011).

Recent research has evaluated the effect that a student's interaction with peers has on his or her performance (the peer effect). ${ }^{5}$ Family-related factors and the support given to a child in the home are usually the most influential factors in terms of cognitive achievement, however. A family's socioeconomic status and household income are the most commonly used proxy variables for these factors.

These variables, in and of themselves, cannot fully capture the unobservable dynamics that take place within the household or what is really going on within its confines in terms of parents' involvement in their children's education and the support they provide. It is important to attempt to avoid underestimating the influence exerted by parents on their children's achievements (Urzúa and Veramendi, 2011, p. 83).

\section{- School-related factors}

These factors have to do with schools' endowments and resources, which ultimately influence students' achievement levels. They can be divided into two categories: the characteristics of the schools, and the characteristics of the teachers.

The variables that are most commonly used to capture the effect of schools' characteristics are the number of books that they possess, their libraries, and other types of infrastructure, such s study halls, the size of classrooms and the equipment that they contain,

5 Epple and Romano (1998); Mizala and Romaguera (2002). technological facilities, etc. However, some studies have shown that the influence exerted by the availability of ICTs on scholastic achievement is limited or virtually nil (Cristia, Czerwonko and Garofalo, 2010; Cristia and others, 2012).

Teachers, on the other hand, can have a strong influence on their students' performance, since they are directly involved on an ongoing basis in their students' learning process. Teachers who do not have the necessary skills or who use ineffective teaching methods can therefore have a negative impact on their students' performance, and the opposite is equally true.

\section{— Institutional factors and education policy}

The organizational structure of a school system has a significant impact on how and what students learn. Institutional factors that can influence students' performance include the distribution of decision-makers' responsibilities in such areas as finance, expenditure and staff movements (hiring and dismissal of teachers) and how much independence schools have in the selection of teaching methods.

Another institutional factor that has gained in importance is the practise of tracking (i.e., the assignment of students to different schools based on their academic level). ${ }^{6}$ Tracking is not used in Costa Rica, however.

\section{Literature on the education production function}

The Coleman study (Coleman, 1966) was one of the first explorations of this subject, and it still has a significant influence on research dealing with academic achievement. It suggests that differences in school-related factors have very little to do with differences in achievement and that family-related factors have a greater influence.

Other studies have reached much the same kinds of conclusions. In his review of the studies that had been conducted up to the mid-1980s, Hanushek (1986) found that evidence of the effect which expenditure per student or other school-related factors have on educational achievement is extremely weak and that this effect disappears altogether when differences in family-related factors are taken into account. More recently, Lee and Barro (2001), who analysed the assessment of the results obtained on the third Trends in International Mathematics and Science Study (TIMSS) in a large number of countries, show that family-related

6 Hanushek and Woessmann (2005 and 2010). 
variables (income, parents' level of education) exert a strong effect on academic achievement. In a study for the Economic Commission for Latin America and the Caribbean (ECLAC), Formichella (2011) examined data on Argentine students' scores on the 2006 PISA test and found that students who live in homes with a more conducive learning environment and more educationrelated resources do better in school.

Thus, in contrast to findings regarding the importance of family-related factors, the evidence on how much influence is exerted by school-related factors is mixed and often inconclusive (Greenwald, Hedges and Laine, 1996; Kremer, 1995; Card and Krueger, 1996).

\section{Fields' decomposition technique}

The literature on inequality, and especially on income inequality, has traced the development of a range of different decomposition methods (Shorrocks 1980, 1982 and 1984; Fields, 2003; Morduch and Sicular 2002). Inequality can be decomposed by subgroups, income sources, causal factors and sociodemographic characteristics; it can also be decomposed at different levels of aggregation. Heshmati (2004) provides an overview of the various methods. In this study, we have opted for Fields' decomposition technique.

This technique, which was developed by Gary S. Fields (2003), is used to decompose the contribution of each explanatory variable to the overall inequality of each dependent variable. It is usually based on the Mincer wage equation and applied in order to determine different variables' roles in accounting for income inequality. In the case of students' performance as measured by the PISA test, the equation (3) is constructed as follows in order to yield the Fields decomposition:

$$
\ln \left(T_{i a}\right)=\sum_{j=1}^{n} C_{i a} * X_{i a j}+\varepsilon_{i a}=\sum_{j=1}^{n} C_{i a} * Z_{i a j}
$$

where: $\ln \left(T_{i a}\right)$ is the natural logarithm of the plausible value;

$X_{i a j}$ are the variables $j$ linked to person $i$ at age $a$ (in years);

$C_{i a}$ are the coefficients for each variable; and

$\varepsilon_{i a}$ is the portion of the variation in students' performances that cannot be explained by the variation among the variables included in the equation.
After applying the variance to each side of the above equation and performing a few mathematical calculations, we have:

$$
1=\frac{\sum_{j} \operatorname{Cov}\left[C_{j} Z_{j}, \ln (T)\right]}{\operatorname{Var} \ln (T)} \cong \sum_{j} S_{j}
$$

where each $S_{j}$ is the "relative weight of the factor in the variation" and is given by:

$$
S_{j}=\frac{\operatorname{Cov}\left(C_{j} Z_{j}, \ln (T)\right)}{\operatorname{Var}(\ln (T))}
$$

The previous equation (5) can be interpreted as the measurement of the proportion of the variance of the logarithm of the plausible value that is explained by each regressor variable $j$. It should be noted that, if the $S_{j}$ of the residual is excluded, then the sum of the relative weights is exactly equal to the measure of the goodness of fit of the regression $\left(\mathrm{R}^{2}\right)$.

This equation can thus be used to estimate the relative weight of each variable in the model in the explanation of students' cognitive performance.

\section{Limitations of the model}

Fields' decomposition technique, like other parametric decomposition techniques, has the disadvantage of imposing a functional form upon the knowledge acquisition process, whereas non-parametric or semiparametric approaches avoid doing so (although the calculations may be extremely complex) (Contreras and Gallegos, 2011, p. 29).

One limitation of the functional form used here is that it does not incorporate a consideration of the dependence of the observations in each group, given the presence of a multi-level structure. A linear model may not be the best way of measuring the relationship between performance on the PISA test and the selected variables.

Nonetheless, the main reason why we have chosen this decomposition technique is that we can use it to quantify the effect of each of the regressors on inequality in education, since it allows us to include dichotomous variables that can then be used to decompose the isolated effect of each explanatory variable. 


\section{VI}

\section{The results at the national level}

The students' scores on the PISA text were used as the dependent variable. ${ }^{7}$ The education production function was estimated both for the entire model, which includes all the students in the sample, and for two subsamples: students attending public schools and students attending private schools. Because of space limitations, only the coefficients for the entire model are given in table A.5 of the annex. ${ }^{8}$

The first point that should be made clear is that $41 \%$ of the differentials in students' cognitive performances is explained by the variables included in the model for the reading test, which means that $59 \%$ correspond to the equation's error term and thus refer to variables that are not in the model. The model's fit for the mathematics and science tests was $43 \%$ and $37 \%$, respectively.

A number of variables proved not to be significant in explaining differences in performance. These included the higher occupational status of some parents, the availability of an Internet connection in the home and the number of computers available in the schools.

When Fields' decomposition technique was applied to the model that included all the students, the following results were obtained (see table A.6 of the annex).

In all three domains, differences in the educational achievements of the students who took the PISA test were mainly accounted for by family- and studentrelated factors.

Although females scored higher than males on the reading test, this cannot be attributed to their gender, since the weight of the variable "female" in the education production function for reading skills is less than $1 \%$. On the other hand, there does seem to be more evidence

\footnotetext{
7 The dependent variable corresponds to the natural logarithm of the plausible value. For each domain, 405 weighted least squares regressions were run using the weightings of the PISA programme database. The regression was also estimated using the plausible value as a dependent variable without applying the natural logarithm. This made it possible to corroborate the fact that the model's fit and the significance of the variables did not change when the natural logarithm was applied to the plausible value.

8 The full sample of 4,578 students was reduced to 4,351 observations owing to data loss. (In all, 227 observations (5\% of the total) were lost, with most of this loss corresponding to family-related and personal variables.) Some variables were not included in the final model in order to avoid a greater loss of data.
}

that gender had an impact on the test results in the areas of science and, in particular, mathematics (4.3\%).

The model indicates that the grade level of the student is the factor that has the greatest effect in terms of differences in educational achievement. Table 2 shows the average scores by grade level:

TABLE 2

Costa Rica: averages scores on the 2009 PISA test of 15-year-old students, by grade level, 2009

\begin{tabular}{lcccccc}
\hline Year & \multicolumn{2}{c}{ Reading } & \multicolumn{2}{c}{ Mathematics } & \multicolumn{2}{c}{ Science } \\
\hline Seventh & 344 & $(5.3)$ & 330 & $(4.5)$ & 346 & $(4.6)$ \\
Eighth & 392 & $(4.1)$ & 367 & $(3.5)$ & 387 & $(3.5)$ \\
Ninth & 442 & $(2.6)$ & 409 & $(2.9)$ & 433 & $(2.7)$ \\
Tenth & 483 & $(3.7)$ & 443 & $(3.6)$ & 462 & $(3.1)$ \\
Eleventh & 498 & $(15.9)$ & 453 & $(19.0)$ & 487 & $(19.7)$ \\
\hline
\end{tabular}

Source: prepared by the authors on the basis of the 2009 PISA assessment database.

Note: the standard deviation is shown in brackets.

As may be seen from the table, the average scores rise steadily by grade level. The ages of the students were not included as a variable in the model because the age range covered by the PISA programme is so short that it would be unlikely to capture the desired effect. Five variables were included, however, that classify each student on the basis of the student's grade level at the time and he or she took the test. This is a better way of capturing the expected average scholastic performance of each student, since it is more likely that those who are in ninth or tenth grade when they are 15 years of age will not have not had to repeat a grade and will have a sufficient knowledge base in the areas of reading, science and mathematics to boost their skill levels and, hence, their scholastic performance. On the other hand, most students who were in seventh or eighth grade at the time that they took the test had repeated at least one grade and were less knowledgeable than students 
in higher grades, which puts them at a disadvantage in terms of test scores.

The PISA assessment is designed to measure capacities and abilities rather than specific knowledge. However, the results suggest that students in higher grades obtain higher scores, and this is the most influential factor in accounting for differences in scholastic performance after controlling for the other factors (gender, nationality, household possessions, public/private school, etc.). The student's grade level accounts for $20.9 \%$ of the inequality in scores on the PISA reading assessment.

The results also indicate that repeating a grade does not resolve students' shortcomings in terms of capacities and abilities, which is what would be required in order for them to score better on the assessment. In addition, the knowledge acquired in each grade could influence the students' analyses and answers on the test, which would also give an advantage to those in higher grades.

When the school-related factors were measured, two variables stood out from all the rest: the type of school (public or private) and the educational resources present in the schools. The first of these variables is the main focus of this study, whose objective is to measure how a student's scholastic performance is affected by the fact that he or she attends a public or private school owing to differences in the quality of education that these two types of schools offer. For the reading scores, $4.11 \%$ of the variation in performance was accounted for by this variable (see table A.6).

Therefore, the type of school is not a strong enough determinant of inequality in students' performances on the PISA assessment to support the statement that the gap between the scholastic performance of public- and private-school students is primarily due to the fact that private schools offer a better education. In the case of the mathematics test, this variable accounted for $3.3 \%$ of the variation in PISA scores; for the science test, it accounted for $6 \%$ of the differential.

The quality of schools' educational resources was the second-most important of the school-related variables: differences in the quality of these resources accounted for nearly $4 \%$ of the variation in the three domains, while institutional factors have barely any impact on the students' scores at all.

In sum, the overall model indicates that familyrelated factors and the students' own characteristics are the variables that account for the largest percentage of differences in students' PISA test scores. This finding is in line with the evidence provided by other studies of this type.

Finally, Fields' decomposition technique was also applied to the public-school and private-school samples (see table A.7 of the annex). For public-school students, the variables included in the model account for smaller percentages of the differences being analysed: $29 \%$ for reading, 34\% for mathematics and $27 \%$ for science. Family-related factors and the student's own characteristics (especially the student's grade level) continue to account for a larger portion of the variation in scores $(27 \%, 29 \%$ and $24 \%$ for reading, mathematics and science, respectively). The role of school-related factors in accounting for differing performances is more limited.

The variables in the model are a better fit in the case of differentials in the performance of students attending private schools $(54 \%, 52 \%$ and $51 \%$ in reading, mathematics and science, respectively), especially since, in this case, institutional factors do turn out to be significant.

For the reading scores, the students' gender did not have an impact on the results (as is also true for the general model), but for mathematics and science, this variable was much more influential.

Differences in the kinds of possessions present in the private-school students' households also play a role in accounting for differing scores $(7 \%, 5 \%$ and $5 \%$ in reading, mathematics and science, respectively), while for the mathematics and science tests, grade-level differences were less influential (9\% and $11 \%$, respectively) than they were for the reading test (16\%).

In the category of school-related factors, private schools with more and better books, computers and laboratories account for $7 \%, 9 \%$ and $5 \%$ of the differentials in the students' scores on the reading, mathematics and science tests, respectively. This is because not all private schools in Costa Rica have the same kinds of resources. The variation seen in private schools in this respect is much greater than it is in public schools, whose available resources are much more uniform.

Institutional factors take on importance in private schools for two reasons: first, these schools enjoy more latitude in terms of the policies that they implement, whereas institutional policies for public schools are standardized; and, second, parent's involvement in the schools' administration has a positive effect on the students' learning process. This could be because parents of students who are attending private schools 
may tend to be more engaged in their children's learning process so that they can monitor the services for which they are paying.

In all three assessment domains, the most influential institutional factor is the availability of extracurricular activities, such as bands and choruses,

\section{VII}

\section{Conclusions}

The Programme for International Student Assessment (PISA) has focused on gauging the quality of education in different countries around the world. Its results allow countries and their citizens to see how their education systems measure up against those of other nations. Costa Rica's participation in this initiative represents a major stride forward, since this will provide its policymakers with a clear picture of the quality of the education offered in the country and the main determinants in that regard.

The PISA programme provides valuable information for future studies on the quality of education in Costa Rica. It is vital that the Ministry of Public Education continues to take part in this programme so that the progress made by the education system can be tracked over time, which will then make it possible to determine how effectively the resources allocated for the education of young Costa Ricans are being used.

The data indicate that the gap between public- and private-school students in Costa Rica is wide. The gap is primarily a function of differences in family-related factors, personal attributes or features of the students, or both, and, among these, especially their grade levels at the time that they take the test. The data obtained from the questionnaires indicate that $26 \%$ of the public-school students who participated in the PISA assessment have repeated one or more grades in secondary school, whereas only $10 \%$ of the private-school students has done so.

The results clearly indicate that a relationship exists between students' grade levels and their academic performance. This underscores how enormously costly it is for students to repeat one or more grades. Having students repeat a grade denies them, to a certain extent, access to knowledge about core subjects and the opportunity to develop the skills that they will need to improve their academic skills. Furthermore, repeating a grade may not be the best approach for dealing with sports teams, debate clubs, etc. $(9.5 \%, 8.8 \%$ and $4.5 \%$ for reading, mathematics and science, respectively), followed by the methods used for evaluating students and teachers, how much independence schools have in deciding how to distribute the resources at their disposal and the degree of academic selectivity. students' academic shortcomings and has, in addition, a demotivating effect.

Resources to provide support for students who have fallen behind in order to reduce repetition rates may be a key tool for improving the quality of Costa Rica's education system. The implementation of changes in the regulations on grade retention and promotion in the public school system since 2009 may help to improve student performance in the future. Before 2009, students in secondary school who failed more than three subjects had to repeat the entire school year, and the Costa Rican education system was therefore highly exclusive. Now, however, thanks to the changes in the regulations, students need not repeat the entire school year. Instead, they will repeat only those subjects that they failed, while continuing on with their other classes in the next grade (except for classes for which the subjects that they failed were prerequisites).

The findings of this research project indicate that these changes in the regulations governing the education system may prove to be of key importance in improving student performance; their actual effect could be measured on the basis of future PISA assessments.

In addition, the difference between the education offered by private schools (which have more and better resources at their command) and the education offered by public schools is not a very important factor when it comes to accounting for the gap in performance between public- and private-school students. In other words, the results demonstrate that, when it comes to finding explanations for differentials in educational performance, socioeconomic conditions exert a much greater influence than differences in the resources available to schools.

It would be advisable for PIS A to send out questionnaires to students' parents, in addition to students and school administrators, so that a more thorough analysis could be made of how family-related factors influence 
students' performance, since these factors have such an enormous explanatory value in terms of scholastic achievement. A questionnaire of this type could provide valuable information about students' homes, activities that parents engage in with their children, discussions about students' progress at school, and even household incomes and the distance that students have to travel to go to school.

Finally, it should be noted that the data gathered by the PISA assessment are reliable enough to be useful in designing policies to narrow the education gaps between different sectors of Costa Rican youths, improve the allocation of public funds and boost the quality of public education. As stated by the Ministry of Public Education in its institutional report for 2006-2010 (Ministry of Public Education, 2010), the country's objective in taking part in international assessments is to use the information that they provide as inputs for efforts to improve teaching and learning experiences, whether by means of curricular reforms, professional development strategies and ongoing training opportunities, or the allocation of resources to provide students with learning support and the application of education policy in the classroom. The information compiled by the PISA assessment is an invaluable input for efforts to improve public education in Costa Rica. 


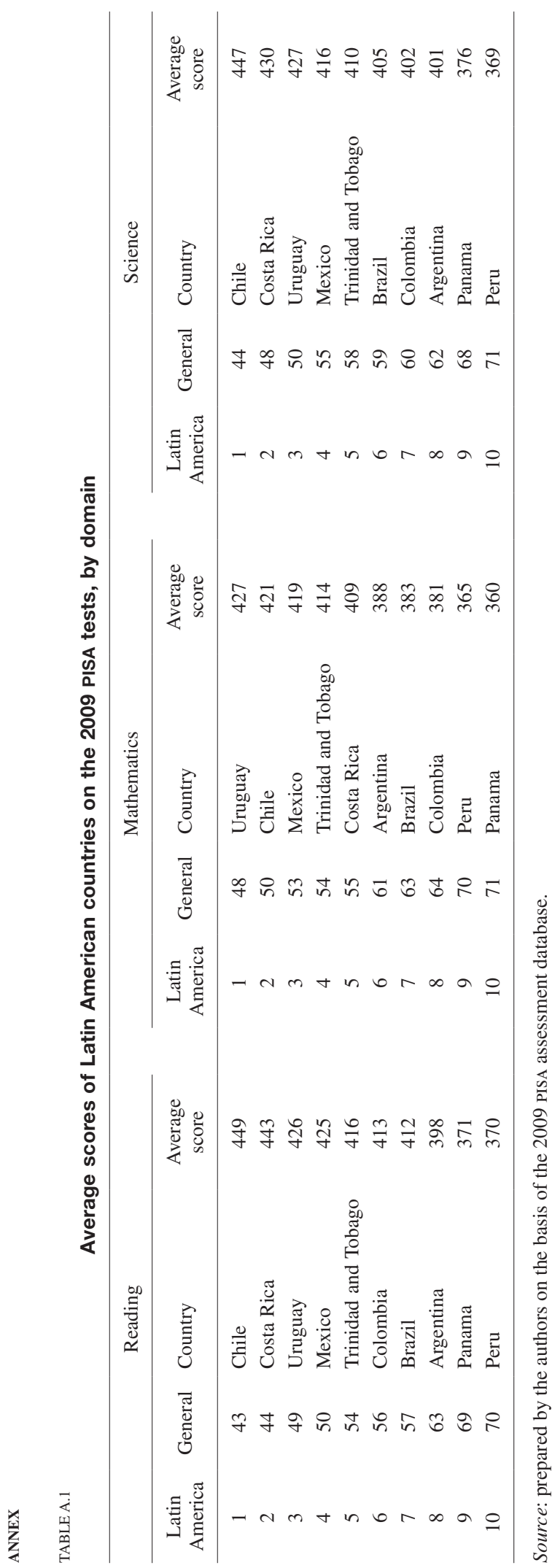


TABLE A. 2

Costa Rica: descriptive statistics for the 2009 PISA assessment, by category

\begin{tabular}{lcc}
\hline Category & Percentage & $\begin{array}{c}\text { Standard } \\
\text { deviation }\end{array}$ \\
\hline Gender & & \\
$\quad$ Female & 53.0 & $(0.6)$ \\
$\quad$ Male & 47.0 & $(0.6)$ \\
Type of school & & \\
$\quad$ Public & 84.6 & $(1.4)$ \\
$\quad$ Private & 15.4 & $(1.4)$ \\
Grade attended & & \\
$\quad$ Seventh & 8.5 & $(0.8)$ \\
$\quad$ Eighth & 16.0 & $(1.0)$ \\
$\quad$ Ninth & 34.1 & $(1.2)$ \\
Tenth & 40.9 & $(1.8)$ \\
Eleventh & 0.4 & $(0.1)$ \\
Twelfth & 0.0 & $(0.0)$ \\
\hline
\end{tabular}

Source: prepared by the authors on the basis of the 2009 PISA assessment database.

TABLE A.3

Costa Rica: descriptive statistics for the assessment, disaggregated by public/private school, student traits and household characteristics, 2009

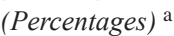

\begin{tabular}{|c|c|c|c|c|}
\hline Characteristic & & & & \\
\hline Female & 5.2 & $(0.7)$ & 51.8 & $(1.8)$ \\
\hline Attended preschool & 74.7 & $(1.3)$ & 91.0 & $(2.0)$ \\
\hline Repeated a grade in school & 18.0 & $(1.2)$ & 4.0 & $(1.4)$ \\
\hline Repeated a grade in lower secondary school (cycle III) & 26.0 & $(1.3)$ & 10.0 & $(1.5)$ \\
\hline Family & & & & \\
\hline Lives with both parents & 68.6 & $(1.1)$ & 78.5 & $(1.8)$ \\
\hline Lives with mother only & 21.2 & $(0.8)$ & 17.1 & $(1.3)$ \\
\hline Lives with father only & 2.1 & $(0.3)$ & 2.0 & $(0.7)$ \\
\hline Does not live with parents & 8.1 & $(0.5)$ & 2.4 & $(1.3)$ \\
\hline Household assets & & & & \\
\hline Room of student's own & 69.5 & $(1.0)$ & 88.2 & $(1.3)$ \\
\hline Desk & 60.1 & (1.3) & 93.1 & $(1.5)$ \\
\hline Computer & 56.5 & $(1.4)$ & 97.3 & $(0.6)$ \\
\hline Internet & 31.0 & (1.3) & 90.9 & $(1.4)$ \\
\hline Art & 39.0 & $(1.1)$ & 81.1 & $(1.7)$ \\
\hline Motor vehicle & 45.5 & $(1.1)$ & 86.7 & $(1.9)$ \\
\hline Bathtub or shower & 62.8 & (1.6) & 98.0 & $(0.6)$ \\
\hline
\end{tabular}

Source: prepared by the authors on the basis of the 2009 PISA assessment database.

Note: the standard deviation is shown in brackets.

a These percentages denote the percentage of students who possess these characteristics, meet these requirements or have these objects in their home. 


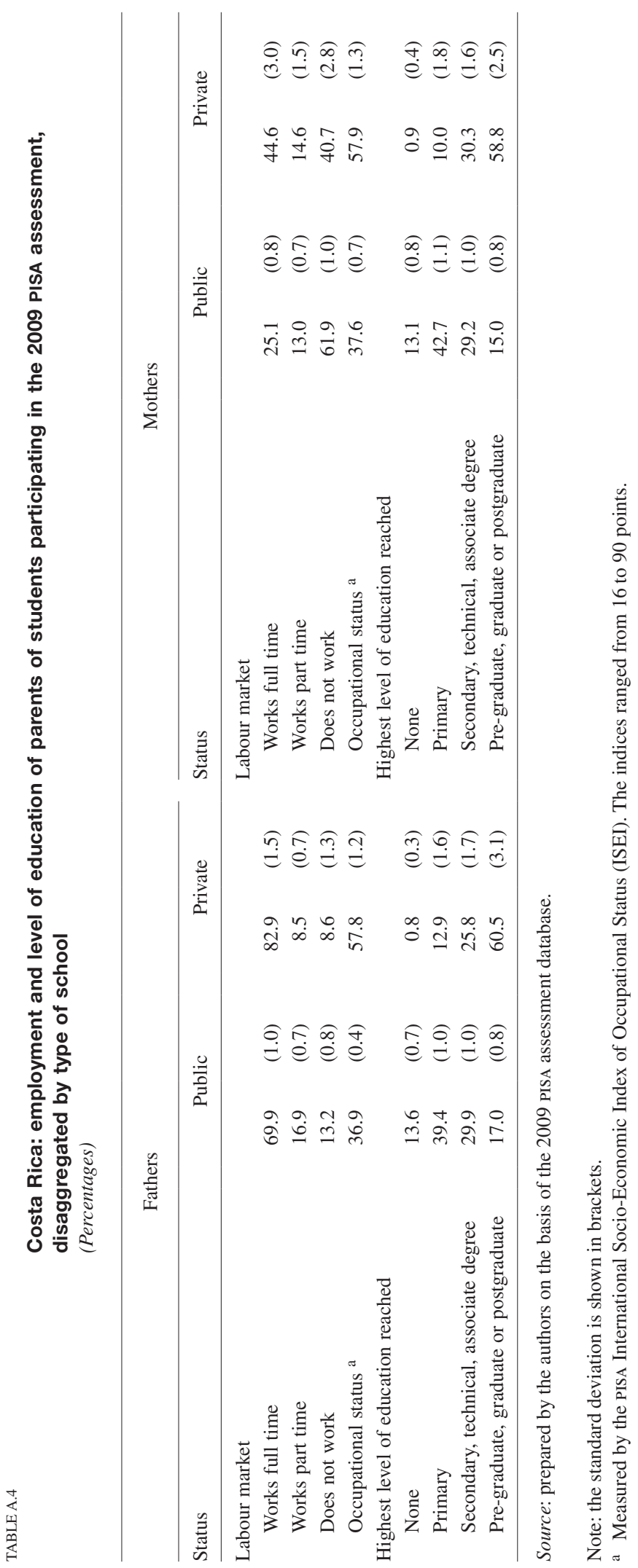


TABLE A.5

Costa Rica: determinants of scholastic achievement.

Coefficients of the education production function, 2009

\begin{tabular}{|c|c|c|c|c|c|c|}
\hline \multirow{3}{*}{$\begin{array}{l}\text { Dependent vaiable: natural logarithm of the plausible value } \\
\text { of the } 2009 \text { PISA assessment a } \\
\text { Constant }\end{array}$} & \multicolumn{6}{|c|}{ Full model } \\
\hline & \multicolumn{2}{|c|}{ Reading } & \multicolumn{2}{|c|}{ Mathematics } & \multicolumn{2}{|c|}{ Science } \\
\hline & 5.732 & $(0.03)$ & 5.805 & $(0.03)$ & 5.802 & $(0.03)$ \\
\hline \multicolumn{7}{|l|}{ Family-related factors and student traits } \\
\hline Female & 0.019 & $(0.00)$ & -0.074 & $(0.00)$ & -0.054 & $(0.00)$ \\
\hline Costa Rican nationality & $0.007^{\mathrm{t}}$ & $(0.01)$ & $-0.001^{\mathrm{t}}$ & $(0.01)$ & $-0.001^{\mathrm{t}}$ & $(0.01)$ \\
\hline Attended preschool & 0.017 & $(0.01)$ & 0.021 & $(0.01)$ & 0.011 & $(0.01)$ \\
\hline Eighth & 0.097 & $(0.01)$ & 0.077 & $(0.01)$ & 0.088 & $(0.01)$ \\
\hline Ninth & 0.173 & $(0.01)$ & 0.151 & $(0.01)$ & 0.165 & $(0.01)$ \\
\hline Tenth & 0.248 & $(0.01)$ & 0.223 & $(0.01)$ & 0.222 & $(0.01)$ \\
\hline Eleventh & 0.299 & $(0.03)$ & 0.269 & $(0.03)$ & 0.294 & $(0.03)$ \\
\hline Occupational status & $0.000^{t}$ & $(0.00)$ & $0.000^{t}$ & $(0.00)$ & $-0.000^{\mathrm{t}}$ & $(0.00)$ \\
\hline \multicolumn{7}{|l|}{ Mother's level of education: } \\
\hline Completed primary & $0.000^{t}$ & $(0.01)$ & 0.016 & $(0.01)$ & $0.015^{\mathrm{t}}$ & $(0.01)$ \\
\hline Completed secondary & $0.014^{\mathrm{t}}$ & $(0.01)$ & 0.037 & $(0.01)$ & $0.014^{\mathrm{t}}$ & $(0.01)$ \\
\hline \multicolumn{7}{|l|}{ Books in the home: } \\
\hline 10 to 25 & 0.015 & $(0.01)$ & $-0.003^{t}$ & $(0.01)$ & 0.016 & $(0.01)$ \\
\hline 25 to 100 & 0.023 & $(0.01)$ & 0.020 & $(0.01)$ & 0.021 & $(0.01)$ \\
\hline 100 to 200 & 0.037 & $(0.01)$ & $0.021^{\mathrm{t}}$ & $(0.01)$ & 0.043 & $(0.01)$ \\
\hline 200 to 500 & 0.055 & $(0.01)$ & 0.033 & $(0.01)$ & 0.053 & $(0.01)$ \\
\hline More than 500 & 0.067 & $(0.03)$ & $0.033^{\mathrm{t}}$ & $(0.03)$ & 0.071 & $(0.03)$ \\
\hline Index of household possessions & 0.009 & $(0.00)$ & 0.010 & $(0.00)$ & $0.002^{\mathrm{t}}$ & $(0.00)$ \\
\hline Index of educational resources in the home & -0.011 & $(0.00)$ & -0.010 & $(0.00)$ & $-0.006^{\mathrm{t}}$ & $(0.00)$ \\
\hline Computer in the home & 0.019 & $(0.01)$ & 0.017 & $(0.01)$ & 0.021 & $(0.01)$ \\
\hline Internet connection in the home & $0.005^{\mathrm{t}}$ & $(0.01)$ & $0.009^{t}$ & $(0.01)$ & 0.017 & $(0.01)$ \\
\hline Peer effect & 0.003 & $(0.01)$ & 0.004 & $(0.01)$ & 0.003 & $(0.01)$ \\
\hline \multicolumn{7}{|l|}{ School-related factors } \\
\hline \multicolumn{7}{|l|}{ Characteristics of the school } \\
\hline Public school & -0.051 & $(0.01)$ & -0.039 & $(0.01)$ & $-0.074^{\mathrm{t}}$ & $(0.01)$ \\
\hline Only school in the area & $0.004^{\mathrm{t}}$ & $(0.01)$ & $-0.006^{\mathrm{t}}$ & $(0.01)$ & -0.002 & $(0.01)$ \\
\hline Computers available for use in studying & $0.000^{\mathrm{t}}$ & $(0.00)$ & $0.000^{t}$ & $(0.00)$ & $-0.000^{\mathrm{t}}$ & $(0.00)$ \\
\hline \multicolumn{7}{|l|}{$\begin{array}{l}\text { Learning process adversely influenced by lack } \\
\text { of insufficient supply of: }\end{array}$} \\
\hline Books & $0.002^{\mathrm{t}}$ & $(0.01)$ & $-0.008^{t}$ & $(0.01)$ & $-0.013^{t}$ & $(0.01)$ \\
\hline Science laboratory & $-0.008^{\mathrm{t}}$ & $(0.01)$ & $-0.005^{\mathrm{t}}$ & $(0.01)$ & $0.014^{\mathrm{t}}$ & $(0.01)$ \\
\hline Computers & $0.004^{t}$ & $(0.01)$ & $-0.008^{t}$ & $(0.01)$ & $0.015^{\mathrm{t}}$ & $(0.01)$ \\
\hline \multicolumn{7}{|l|}{ Characteristics of teachers } \\
\hline \multicolumn{7}{|l|}{$\begin{array}{l}\text { Learning process adversely influenced by unqualified } \\
\text { teachers of: }\end{array}$} \\
\hline Reading & $0.010^{\mathrm{t}}$ & $(0.01)$ & $0.010^{\mathrm{t}}$ & $(0.01)$ & $0.003^{\mathrm{t}}$ & $(0.01)$ \\
\hline Mathematics & $-0.011^{\mathrm{t}}$ & $(0.01)$ & -0.019 & $(0.01)$ & $-0.017^{\mathrm{t}}$ & $(0.01)$ \\
\hline Science & $0.003^{\mathrm{t}}$ & $(0.01)$ & 0.026 & $(0.01)$ & $0.015^{\mathrm{t}}$ & $(0.01)$ \\
\hline \multicolumn{7}{|l|}{ Institutional factors } \\
\hline Tracking & 0.001 & $(0.01)$ & 0.002 & $(0.01)$ & $0.002^{\mathrm{t}}$ & $(0.01)$ \\
\hline Index of school leadership & -0.009 & $(0.00)$ & -0.009 & $(0.00)$ & $-0.001^{\mathrm{t}}$ & $(0.00)$ \\
\hline Index of extracurricular activities & 0.019 & $(0.00)$ & 0.013 & $(0.00)$ & 0.016 & $(0.00)$ \\
\hline \multicolumn{7}{|l|}{ Index of school responsibility for: } \\
\hline Curriculum and evaluation & $0.001^{\mathrm{t}}$ & $(0.00)$ & $-0.002^{t}$ & $(0.00)$ & $-0.001^{\mathrm{t}}$ & $(0.00)$ \\
\hline Distribution of resources & -0.011 & $(0.01)$ & -0.014 & $(0.01)$ & $-0.005^{\mathrm{t}}$ & $(0.01)$ \\
\hline No. of observations & \multicolumn{2}{|c|}{4351} & \multicolumn{2}{|c|}{4351} & \multicolumn{2}{|c|}{4351} \\
\hline Adjusted $\mathrm{R}^{2}$ & \multicolumn{2}{|c|}{0.412} & \multicolumn{2}{|c|}{0.429} & 0.3 & \\
\hline
\end{tabular}

Source: prepared by the authors on the basis of the 2009 PISA assessment database.

Note: the standard deviation is shown in brackets.

a For each domain, 405 weighted least squares regressions were run.

$\mathrm{t}$ Variable not significant at $5 \%$. 
TABLE A.6

Costa Rica: decomposition of the effect of each EPF factor on scholastic performance of 15-year-olds, 2009

(Percentages)

\begin{tabular}{lrrr}
\hline & Reading & Mathematics & Science \\
\hline Family-related factors and student traits & 30.91 & 31.84 & 27.04 \\
$\quad$ Female & 0.87 & 4.36 & 2.11 \\
Attended preschool & 0.74 & 1.02 & 0.39 \\
$\quad$ Grade attended & 20.90 & 17.54 & 16.61 \\
Occupational status & 0.22 & 0.19 & 0.00 \\
$\quad$ Mother's level of education & 1.14 & 2.39 & 1.17 \\
Books in the home & 2.71 & 1.88 & 2.64 \\
Possessions and educational resources in the home & 2.41 & 3.13 & 2.41 \\
$\quad$ Peer effect & 1.92 & 1.33 & 1.71 \\
School-related factors & 9.40 & 10.23 & 9.35 \\
Characteristics of the school & 8.92 & 9.55 & 8.92 \\
$\quad$ Public school & 4.11 & 3.31 & 6.04 \\
Only school in the area & 0.03 & 0.00 & 0.01 \\
Headmistress & 0.16 & 0.20 & 0.00 \\
Index of educational resources in the school & 4.45 & 4.22 & 3.42 \\
Computers available for use in studying & 0.13 & 0.19 & 0.00 \\
$\quad$ Lack of books, laboratory, computers & 0.04 & 1.63 & -0.55 \\
Characteristics of teachers & 0.48 & 0.68 & 0.43 \\
Institutional factors & 0.89 & 0.83 & 0.71 \\
\hline Total & 41.2 & 42.9 & 37.1 \\
\hline
\end{tabular}

Source: prepared by the authors on the basis of the 2009 PISA assessment database.

EPF: education production function. 
Costa Rica: decomposition of the effect of each EPF factor on scholastic performance of 15-year-olds, disaggregated by type of school, 2009

(Percentages)

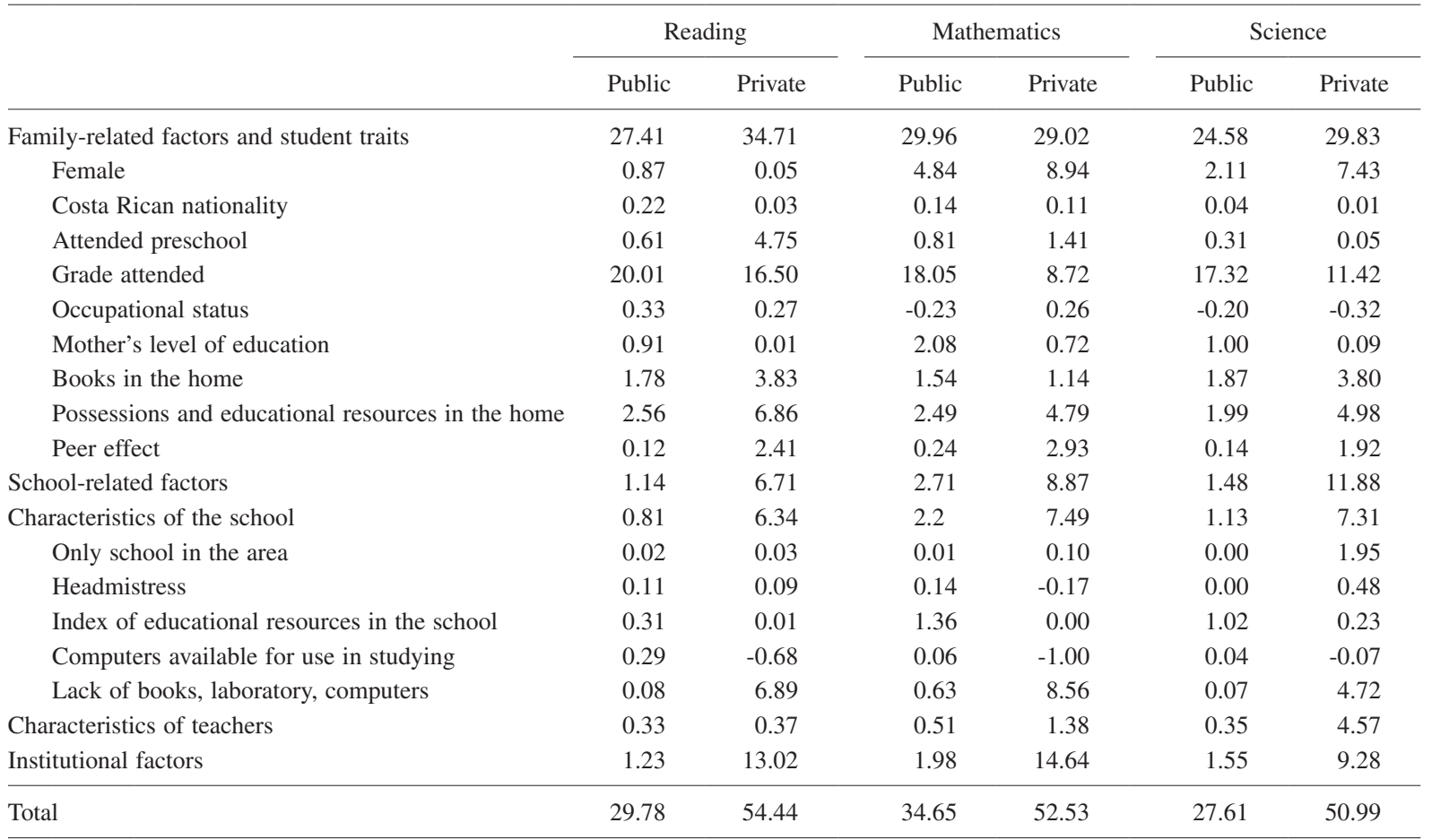

Source: prepared by the authors on the basis of the 2009 PISA assessment database.

EPF: education production function. 


\section{Bibliography}

Card, D. and A. Krueger (1996), "School resources and student outcomes: an overview of the literature and new evidence from North and South Carolina", Journal of Economic Perspectives, vol. 10, No. 4, Nashville, Tennessee, American Economic Association.

Coleman, J. (1966), Equality of Educational Opportunity, Washington, D.C., Department of Health, Education and Welfare.

Contreras, D. and S. Gallegos (2011), "Wage inequality in Latin America: a decade of changes", CEPAL Review, No. 103 (LC/G.2487-P), Santiago de Chile, April.

Cristia, J., A. Czerwonko and P. Garofalo (2010), "Does ICT Increase Years of Education? Evidence from Peru", OVE Working Papers, No. 110, Washington, D.C., Inter-American Development Bank (IDB).

Cristia, P. and others (2012), "Technology and child development: evidence from the one laptop per child program", IDB Working Paper Series, No. 304, Washington, D.C., Department of Research and Chief Economist, Inter-American Development Bank (IDB).

Díaz Porras, R. and R. Jiménez Rodríguez (1980), "Consideraciones económicas sobre el sistema educativo costarricense", thesis for the degree of licenciatura, San José, Schools of Economics, University de Costa Rica.

Epple, D. and R. Romano (1998), "Competition between private and public schools, vouchers, and peer-group effects", American Economic Review, vol. 88, No. 1, Nashville, Tennessee, American Economic Association.

Estado de la Nación (2011), Informe III. Nuevos Instrumentos para el Análisis de la Education en Costa Rica, San José, Programa Estado de La Nación.

Fields, G.S. (2003), "Accounting for income inequality and its change: a new method, with application to the distribution of earnings in the United States", Research in Labor Economics, vol. 22, Bingley, Emerald.

Formichella, M. (2011), "Do private schools in Argentina perform better because they are private?", CEPAL Review, No. 105 (LC/G.2508-P), Santiago, Chile.

Greenwald, R., L. Hedges and R. Laine (1996), "The effect of school resources on student achievement", Review of Educational Research, vol. 66, No. 3, Washington, D.C., American Educational Research Association

Hanushek, E. (1986), "The economics of schooling: production and efficiency in public schools", Journal of Economic Literature, vol. 24, No. 3, Nashville, Tennessee, American Economic Association.

(1979), "Conceptual and empirical issues in the estimation of educational production functions", The Journal of Human Resources, vol. 14, No. 3, Madison, University of Wisconsin Press.

Hanushek, E. and L. Woessmann (2010), "The Economics of International Differences in Educational Achievement", NBER Working Paper, No. 15949, Cambridge, Massachusetts, National Bureau of Economic Research.

(2005), "Does Educational Tracking Affect Performance and Inequality? Differences-in-Differences Evidence Across
Countries", nber Working Paper, No. 11124, Cambridge, Massachusetts, National Bureau of Economic Research.

Heshmati, A. (2004), "A Review of Decomposition of Income Inequality", IZA Discussion Paper, No. 1221, Bonn, Institute for the Study of Labor (IZA).

Kremer, M. (1995), "Research on schooling: what we know and what we don't. A comment on Hanushek", World Bank Research Observer, vol. 10, No. 2, Washington, D.C., Oxford University Press.

Lee, J. and R. Barro (2001), "Schooling quality in a cross-section of countries", Economica, vol. 68, No. 272, London, London School of Economics and Political Science.

Ministry of Public Education (2010), Educando en tiempos de cambio: memoria institucional 2006-2010, San José.

Mizala, A. and P. Romaguera (2002), "Equity and Educational Performance", Working Paper No. 136, Santiago, Chile, Centre for Applied Economics, University of Chile.

Morduch, J. and T. Sicular (2002), "Rethinking inequality decomposition, with evidence from rural China", Economic Journal, vol. 112, No. 476, St. Andrews, Royal Economic Society.

Moreira Mora, T. (2009), "Factores endógenos and exógenos asociados al rendimiento en matemática: un análisis multinivel", Revista Educación, vol. 33, No. 2, San José, University of Costa Rica.

OECD (Organization for Economic Cooperation and Development) (2012), PISA 2009 Technical Report, Paris, OECD Publishing. (2009), PISA Data Analysis Manual: SPSS and SAS, Paris, OECD Publishing.

Shorrocks, A. (1984), "Inequality decomposition by population subgroups", Econometrica, vol. 52, No. 6, New York, The Econometric Society.

(1982), "Inequality decomposition by factor components", Econometrica, vol. 50, No. 1, New York, The Econometric Society. (1980), "The class of additively decomposable inequality", Econometrica, vol. 48, No. 3, New York, The Econometric Society.

Todd, P.E. and K.I. Wolpin (2003), "On the specification and estimation of the production function for cognitive achievement", The Economic Journal, vol. 113, No. 485, St. Andrews, Royal Economic Society.

UNESCO (United Nations Educational, Scientific and Cultural Organization) (2008), Los aprendizajes de los estudiantes de América Latina y el Caribe, Santiago, Chile, UNESCo Regional Office for Education in Latin America and the Caribbean.

Urzúa, S. and G. Veramendi (2011), "The impact of out-of-home child care centers on early childhood development", IDB Working Paper Series, No. IDB-WP-240, Washington, D.C., Inter-American Development Bank (IDB).

Vegas, E. and J. Petrow (2007), Raising Student Achievement in Latin America: The Challenge for the 21st Century, Washington, D.C., World Bank

Walker, M. (2011), PISA 2009 PLUS Results: Performance of 15-yearolds in Reading, Mathematics and Science for 10 Additional Participants, Melbourne, ACER Press.

Woessmann, L. (2011), Schooling Resources, Educational Institutions, and Student Performance: The International Evidence, Kiel, Kiel Institute for the World Economy. 